\title{
FORMULASI WHOLE BANANA (Musa paradisiaca l. L.) BISKUIT TINGGI SERAT BERPOTENSI MENCEGAH PENYAKIT DEGENERATIF PADA LANSIA
}

\author{
Septiani $^{1,}$ Isti Istianah ${ }^{2}$ dan Mia Srimiati ${ }^{3}$ \\ ${ }^{1}$ Kampus Universitas Binawan. D/a. J1. Raya Kalibata No.25 RT.12/RW.5, Kecamatan Kramat \\ Jati, Kota Jakarta Timur, Propinsi DKI Jakarta, Indonesia \\ E-mail: septiani@binawan.ac.id
}

\section{WHOLE BANANA FORMULATION (Musa paradisiaca l. L.) BISCUIT HIGH FIBER POTENTIAL TO PREVENT DEGENERATIVE DISEASES FOR LANSIA}

\begin{abstract}
This research aims to analyze the effect of the substitution of the whole banana (Musa paradisiaca l.) High-fiber biscuits to prevent degenerative diseases in the elderly. This experimental research design uses a Completely randomized design (CRD) with one control formula and four substitution levels including FO (100\% wheat flour), F1 (50\% wheat flour and 50\% kepok banana peel flour), F2 (45\% wheat flour and $55 \%$ kepok banana peel flour), F3 (40\% flour and 60\% banana peel flour) and F4 (35\% flour and $65 \%$ of banana peel flour). .The results of the proximate analysis of selected whole banana (musa paradisiaca l.) biscuits contain $16.64 \%$ fiber, $63.18 \%$ carbohydrate, $21.58 \%$ fat, $5.64 \%$ protein, $469.50 \mathrm{kcal} / 100 \mathrm{~g}$ energy, $6.49 \%$ water, and $3.11 \%$ ash. This research concludes that the control formula biscuits is significant differences from the selected whole banana (musa paradisiaca l.) biscuits formula $(p<0.05)$ in in each analysis (water, ash, fat, protein, carbohydrate, and fiber).
\end{abstract}

Keywords : Kepok banana peel, whole banana (Musa Paradisiaca L.) biscuits, fiber

\begin{abstract}
Abstrak
Penelitian ini bertujuan untuk mengetahui formulasi whole banana (musa paradisiaca l.) biskuit tinggi serat untuk mencegah penyakit degeneratif pada lansia. Desain penelitian ekperimental ini menggunakan Rancangan Acak Lengkap (RAL) dengan satu kontrol dan empat tingkatan substitusi yaitu F0 (100\% tepung terigu), F1 (50\% tepung terigu dan $50 \%$ tepung kulit pisang kepok), F2 (45\% tepung terigu dan 55\% tepung kulit pisang kepok), F3 (40\% tepung terigu dan 60\% tepung kulit pisang kepok) dan F4 (35\% tepung terigu dan 65\% tepung kulit pisang kepok). uji organoleptik mengunakan uji ANOVA, apabila signifikan dilanjutkan dengan uji lanjut . asil kadar proksimat dan kadar serat. Hasil analisis organoleptik uji hedonik menunjukkan whole banana (musa paradisiaca l.) biskuit formula terpilih yaitu F3. Hasil analisis proksimat whole banana (musa paradisiaca l.) biskuit terpilih mengandung serat sebesar 16,64\%, karbohidrat sebesar $63,18 \%$, lemak sebesar $21,58 \%$, protein sebesar 5,64\%, energi sebesar 469,50 kkal $/ 100 \mathrm{~g}$, kadar air sebesar 6,49\% dan kadar abu sebesar 3,11\%. Kesimpulan penelitian ini adalah biskuit formula kontrol berbeda nyata dengan whole banana (musa paradisiaca l.) biskuit formula terpilih $(\mathrm{p}<0,05)$ pada semua uji sifat kimia (kadar air, kadar abu, lemak, protein, karbohidrat, dan kadar serat).
\end{abstract}

Kata kunci: kulit pisang kepok, whole banana (musa paradisiaca l.) biskuit, serat 


\section{PENDAHULUAN}

Peningkatan usia harapan hidup merupakan salah satu indikator keberhasilan pembangunan suatu negara. Peningkatan usia harapan hidup berbanding lurus dengan peningkatan jumlah lansia. Kemenkes RI menyatakan bahwa jumlah lansia di Indonesia sebanyak 23,66 juta jiwa atau $9,03 \%$ dari total penduduk Indonesia dan diperkirakan angka tersebut akan terus meningkat setiap tahunnya ${ }^{1}$. Namun, meningkatnya jumlah lansia berarti meningkat juga kemungkinan naiknya kasus penyakit degeneratif, seperti penyakit jantung, hipertensi, gangguan gastrointestinal hingga konstipasi ${ }^{2}$. Munculnya penyakit degeneratif dapat disebabkan oleh berbagai faktor, seperti usia, pola makan, dan pola hidup $^{3}$.

Kandungan serat pektin pada kulit pisang kepok dapat mengatasi gangguan konstipasi. Kandungan pektin dalam kulit pisang kepok berkisar antara 10.10\% $11.93 \%$. Pektin merupakan salah satu jenis serat pangan yang memiliki fungsi utama sebagai penstabil. Sedangkan dalam dunia kesehatan pektin biasanya dimanfaatkan sebagai antidiare absorben yang dapat mengurangi hiperosmorilita ${ }^{4}$.

Pada umumnya, pengolahan tepung kulit pisang kepok dijadikan produk pangan, seperti Biskuit, Wafer dan Es Krim. Penambahan tepung kulit pisang pada pengolahan Biskuit akan menambah nilai gizi dan kualitas produk makanan. Biskuit dapat menjadi alternatif pengobatan nonfarmokologi yang sangat efisien dalam membantu mengatasi penyakit kontipasi pada lansia karena sangat mudah dicerna oleh tubuh.

Kadar serat dari cookies dengan subsitusi $25 \%$ tepung kulit pisang sebesar $15,34 \%$ dengan nilai kesukaan pada rasa sebesar 3,80, pada aroma 3,45, pada tekstur 3,70 dan warna 3,65 , yang artinya panelis menyukainya ${ }^{5}$. Agustono, et all melakukan penelitian untuk fermentasi kulit pisang dan analisis proksimat sebagai bahan pakan alternatif pada formulasi pakan ikan mas dan diperoleh hasil bahwa kadar serat yang yang terkandung pada tepung kulit kulit pisang adalah sebesar $19,10 \%$ dan menyimpulkan bahwa subsitusi tepung kulit pisang kepok pada pakan ikan mas diharapkan dapat meningkatkan produksi dengan waktu pemeliharaan yang singkat dan lebih ekonomis 6 .

Berdasarkan studi literatur yang telah dilakukan, sampai saat ini penelitian terkait penambahan tepung pisang kepok sebagai bahan penstabil dan pangan tinggi serat pada bahan makanan berupa Biskuit masih 
terbatas, sehingga diperlukannya penelitian lebih lanjut mengenai formulasi whole banana (musa paradisiaca l.) biskuit tinggi serat yang berpotensi mencegah penyakit degeneratif pada lansia.

\section{BAHAN DAN METODE}

\section{Waktu dan Tempat Penelitian}

Penelitian dilakukan pada bulan Maret - September 2020 yang bertempat di Laboratorium Kuliner Universitas Binawan, Jakarta dan di Laboratorium Saraswanti Indo Genetech, Bogor.

Alat yang digunakan adalah pisau, timbangan makanan, kompor, mixer, blender, ayakan 80 mesh, oven, loyang, sendok, pengaduk, baskom, pipet tetes, timbangan analitik, alat-alat gelas penunjang serta seperangkat alat uji organoleptik. Bahan yang digunakan dalam penelitian adalah tepung kulit pisang kepok, tepung terigu, telur, mentega, gula pasir, bahan pelembut (SP), susu bubuk.

Variabel dalam penelitian ini terbagi menjadi dua yaitu : variabel independen adalah persentase tepung terigu dengan tepung kulit pisang kepok pada pembuatan biskuit. Variabel dependen adalah hasil uji hedonik, mutu hedonik, dan uji analisis proksimat, dan serat.
Desain penelitian ekperimental ini menggunakan Rancangan Acak Lengkap (RAL) dengan perlakuan perbandingan tepung terigu dan kulit pisang kepok yang terdiri dari lima perlakuan dan dua kali pengulangan. Parameter yang diamati meliputi kadar air, kadar abu, kadar lemak, kadar serat kasar, kadar karbohidrat, kadar protein, kadar energi dan penilaian organoleptik secara deskriptif dan hedonik yang meliputi warna, aroma, rasa, tekstur serta penilaian kesukaan secara keseluruhan terhadap whole banana (musa paradisiaca l.) biskuit yang dihasilkan.

Persentase formulasi dilakukan melalui empat tingkatan substitusi yaitu F1 (50\% tepung terigu dan 50\% tepung kulit pisang kepok), F2 (45\% tepung terigu dan 55\% tepung kulit pisang kepok), F3 (40\% tepung terigu dan $60 \%$ tepung kulit pisang kepok) dan F4 (35\% tepung terigu dan 65\% tepung kulit pisang kepok), dengan F0 (0\% tepung kulit pisang kepok dan 100\% tepung terigu) sebagai kontrol.

Pengolahan data pada penelitian ini menggunakan Microsoft dan program statistik komputer. Data hasil uji hedonik dan uji mutu hedonik, dianalisis dengan deskriptif, selanjutnya diuji statistik menggunakan Analysis of Variance 
(ANOVA). Jika ANOVA menunjukkan dan gula dikocok hingga mengembang lalu pengaruh pelakuan nyata, maka dilanjutkan dengan Duncan's Multiple Range Test (DMRT) pada taraf 5\% untuk mencari keberadaan perbedaan dari pelakuan yang ada.

\section{Pelaksanaan Penelitian}

a) Pembuatan Tepung Kulit Pisang Kepok

Tahap pertama pembuatan tepung kulit pisang kepok adalah menyiapkan 1 kilogram kulit pisang kepok, kemudian dibersihkan dan dipotong menjadi bagian kecil dengan ukuran kurang lebih $1 \mathrm{~cm} \quad \mathrm{x} \quad 0,5 \mathrm{~cm}$ menggunakan pisau. Kulit pisang kepok direndam ke dalam larutan natrium metabisulfit selama 15 menit dan ditiriskan. Tahap selanjutnya kulit pisang kepok dikeringkan menggunakan Oven dengan Suhu $60^{\circ} \mathrm{C}$ Selama 9 Jam. Setelah kering digiling menggunakan Blender dan diayak menggunakan ayakan 80 mesh untuk memisahkan bagian kasar dengan bagian halus kemudian tepung kulit pisang kepok disimpan di wadah kedap udara.

b) Pembuatan whole banana (musa paradisiaca l.) biskuit

Pembuatan whole banana (musa paradisiaca l.) biskuit dilakukan dengan penimbangan bahan-bahan kemudian telur dimasukkan mentega, butter, dan baking powder kedalam adonan, diaduk hingga warna pucat kemudian tahap selanjutnya dimasukkan tepung terigu, tepung kulit pisang kepok, dan susu bubuk, diaduk hingga tercampur rata. Adonan lalu dicetak dengan dengan cetakan. Setelah itu di panggang dalam oven dengan suhu $130^{\circ} \mathrm{C}$ selama 35 menit. Biskuit yang sudah jadi kemudian dikemas dalam plastik kedap udara.

\section{HASIL}

\section{Uji Organoleptik Whole Banana (Musa} paradisiaca l.) Biskuit

Uji organoleptik bertujuan untuk penilaian penggunaan bahan bahan formulasi terhadap whole banana (musa paradisiaca l.) biskuit dengan tingkatan substitusi tepung kulit pisang antara lain 0\% (F0); 50\% (F1); $55 \%$ (F2); 60\% (F3) dan 65\% (F4). Hasil luaran whole banana (musa paradisiaca l.) biskuit yang diperoleh dari formulasi yang telah dibuat dapat dilihat pada Gambar 1. 


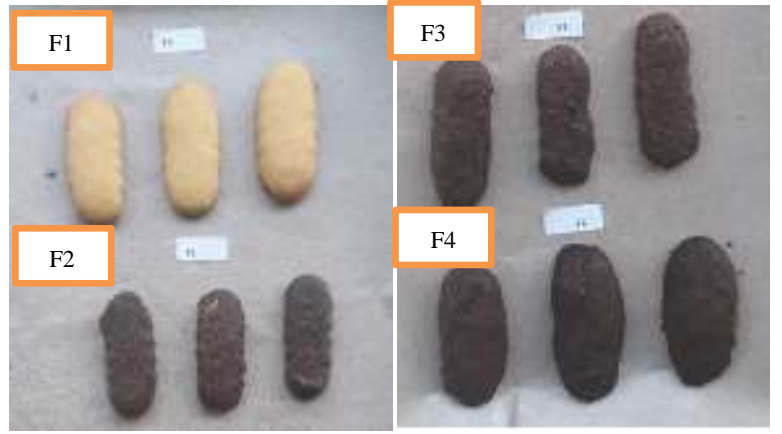

Gambar 1. Penampakan Whole Banana (Musa paradisiaca l.) Biskuit Tepung Kulit Pisang Kepok

Persentase formula terpilih dilakukan dengan cara melihat nilai rata-rata tertinggi dari uji tingkat kesukaan (uji hedonik). Hasil dari masing-masing atribut penilaian dianalisis secara deskriptif dan statistik dengan uji beda lebih dari dua kelompok menggunakan uji sidik ragam (ANOVA) kemudian dilanjutkan dengan uji lanjut duncan. Hasil uji hedonik dan uji mutu hedonik whole banana (musa paradisiaca l.) biskuit tepung kulit pisang kepok dapat dilihat pada Tabel 1 dan Tabel 2.

\section{Penentuan Formula Terpilih}

Formula terpilih ditentukan berdasarkan hasil uji tingkat kesukaan (hedonik) sepertikan yang tampilkan pada Tabel 1. Penilaian formula terpilih berasal dari nilai kesukaan secara keseluruhan. Berdasarkan hasil uji hedonik whole banana (musa paradisiaca l.) biskuit pada tingkatan F3 (60\%) memiliki karakteristik yang paling tinggi dibandingkan dengan F1 (50\%), F2
(55) dan F4 (65\%). Hasil karakteristik mutu hedonik whole banana (musa paradisiaca l.) biskuit F3 (60\%) dari segi rasa yaitu biasa menuju manis $(3,37)$, tekstur biasa menuju lembut $(3,47)$, warna coklat tua $(3,23)$, dan aroma biasa saja menuju wangi $(3,53)$.

Analisis Proksimat Whole Banana (Musa paradisiaca l.) Biskuit Tepung Kulit Pisang Kepok Formula Terpilih

Analisis proksimat dilakukan pada tepung pisang kepok dan whole banana (musa paradisiaca l.) biskuit. Analisis proksimat meliputi analisis kandungan karbohidrat, lemak, protein, jumlah energi, kadar air, kadar abu dan sukrosa dari whole banana (musa paradisiaca l.) biskuit untuk formula kontrol dan formula terpilih. Selain analisis proksimat juga dilakukan analisis serat. Data hasil analisis pada formula terpilih dijelaskan secara deskriptif dan dibandingkan dengan formula kontrol, serta dilakukan uji beda (Independent Sample ttest) untuk mengetahui adanya perbedaan antara formula kontrol dan formula terpilih. Hasil analisis proksimat whole banana (musa paradisiaca l.) biskuit formula kontrol dan formula terpilih disajikan pada Tabel 3 dan Tabel 4. 
Tabel 1. Hasil Uji Hedonik Whole Banana (Musa paradisiaca l.) Biskuit Substitusi Tepung Kulit Pisang Kepok

\begin{tabular}{cccccc}
\hline \multirow{2}{*}{ Formula } & \multicolumn{5}{c}{ Atribut } \\
\cline { 2 - 6 } & Rasa & Tekstur & Warna & Aroma & Keseluruhan \\
\hline F0 & $4,07^{\mathrm{b}}$ & $3,63^{\mathrm{a}}$ & $4,07^{\mathrm{b}}$ & $3,93^{\mathrm{b}}$ & $3,92^{\mathrm{d}}$ \\
F1 & $3,10^{\mathrm{a}}$ & $3,47^{\mathrm{a}}$ & $3,07^{\mathrm{a}}$ & $3,50^{\mathrm{a}}$ & $3,28^{\mathrm{a}}$ \\
F2 & $3,33^{\mathrm{a}}$ & $3,33^{\mathrm{a}}$ & $3,17^{\mathrm{a}}$ & $3,37^{\mathrm{a}}$ & $3,30^{\mathrm{ab}}$ \\
F3 & $3,37^{\mathrm{a}}$ & $3,47^{\mathrm{a}}$ & $3,23^{\mathrm{a}}$ & $3,53^{\mathrm{a}}$ & $3,40^{\mathrm{c}}$ \\
F4 & $3,20^{\mathrm{a}}$ & $3,53^{\mathrm{a}}$ & $3,17^{\mathrm{a}}$ & $3,43^{\mathrm{a}}$ & $3,33^{\mathrm{b}}$ \\
\hline
\end{tabular}

Tabel 2. Hasil Uji Mutu Hedonik Whole Banana (Musa paradisiaca l.) Biskuit Substitusi Tepung Kulit Pisang Kepok

\begin{tabular}{cccccc}
\hline \multirow{2}{*}{ Formula } & \multicolumn{5}{c}{ Atribut } \\
\cline { 2 - 6 } & Rasa & Tekstur & Warna & Aroma & Keseluruhan \\
\hline F0 & $4,07^{\mathrm{b}}$ & $3,37^{\mathrm{b}}$ & $4,70^{\mathrm{c}}$ & $4,00^{\mathrm{a}}$ & 4,03 \\
F1 & $2,97^{\mathrm{a}}$ & $2,73^{\mathrm{a}}$ & $2,60^{\mathrm{b}}$ & $3,27^{\mathrm{b}}$ & 2,89 \\
F2 & $3,83^{\mathrm{a}}$ & $2,67^{\mathrm{a}}$ & $2,40^{\mathrm{b}}$ & $3,47^{\mathrm{b}}$ & 3,09 \\
F3 & $3,00^{\mathrm{a}}$ & $3,07^{\mathrm{ab}}$ & $2,27^{\mathrm{b}}$ & $3,40^{\mathrm{b}}$ & 2,93 \\
F4 & $2,77^{\mathrm{a}}$ & $3,40^{\mathrm{b}}$ & $1,87^{\mathrm{a}}$ & $3,37^{\mathrm{b}}$ & 2,85
\end{tabular}

Keterangan : Skala atribut yaitu $1=$ sangat tidak suka hingga $5=$ sangat suka.

: Huruf yang beda pada baris yang sama menunjukkan perbedaan yang nyata $(\mathrm{p}<0,05)$.

Tabel 3. Hasil Analisis Proksimat Tepung kulit Pisang Kepok

\begin{tabular}{lcc}
\hline \multicolumn{1}{c}{ Komponen } & Tepung kulit Pisang Kepok & $\boldsymbol{p}$-value \\
\hline Karbohidrat (\%) & 62,91 & $0,000^{*}$ \\
Lemak (\%) & 12,23 & $0,000^{*}$ \\
Protein (\%) & 7,26 & $0,000^{*}$ \\
Serat Pangan (\%) & 51,21 & $0,000^{*}$ \\
Energi (kkal/100 g) & 390,75 & $0,000^{*}$ \\
Kadar Air (\%) & 8,82 & $0,000^{*}$ \\
Kadar Abu (\%) & 8,78 & $0,000^{*}$ \\
Sakarosa (\%) & Tidak Terdeteksi & $0,000^{*}$
\end{tabular}

Keterangan: *) perbedaan secara signifikan $(\mathrm{p}<0,05)$ 
Tabel 4. Hasil Analisis Proksimat Whole Banana (Musa Paradisiaca) Biskuit Formula Kontrol F0 (0\%) dan Formula Terpilih F3 (60\%)

\begin{tabular}{lccc}
\hline \multicolumn{1}{c}{ Komponen } & $\begin{array}{c}\text { Formula } \\
\text { Kontrol }\end{array}$ & $\begin{array}{c}\text { Formula Terpilih } \\
(\mathbf{F 3})\end{array}$ & $\begin{array}{c}\boldsymbol{p} \text { - } \\
\text { value }\end{array}$ \\
\hline Karbohidrat (\%) & 66.91 & 63,18 & $0,000^{*}$ \\
Lemak (\%) & 19.68 & 21,58 & $0,000^{*}$ \\
Protein (\%) & 6.64 & 5,64 & $0,000^{*}$ \\
Serat Pangan (\%) & 8.76 & 16,64 & $0,000^{*}$ \\
Energi (kkal/100 g) & 471,32 & 469,50 & $0,000^{*}$ \\
Kadar Air (\%) & 5,76 & 6,49 & $0,000^{*}$ \\
Kadar Abu (\%) & 1,01 & 3,11 & $0,000^{*}$ \\
Sakarosa (\%) & 20,25 & 18,52 & $0,000^{*}$ \\
\hline
\end{tabular}

Keterangan: *) perbedaan secara signifikan $(\mathrm{p}<0,05)$

\section{PEMBAHASAN}

\section{Uji Organoleptik}

Uji organoleptik yang dilakukan adalah uji hedonik (kesukaan) dan uji mutu hedonik. Kriteria yang dijadikan parameter dalam persentase formulasi adalah warna, tekstur, rasa dan aroma dari biskuit dengan perlakuan menambahkan tepung kulit pisang kepok terhadap formula kontrol. Pengujian organoleptik dilakukan pada whole banana (musa paradisiaca l.) biskuit dengan komposisi F0 (0\%) sebagai formula kontrol, F2 $(50 \%)$, F3 (55\%), F3 (60\%) sebagai formula terpilih dan F4 (65\%) memberikan hasil yang secara keseluruhan tidak berbeda nyata dari segi rasa, warna, aroma dan tekstur (Tabel 1). Berdasarkan hasil uji hedonik, formulasi F3 dengan komposisi tepung kulit pisang sebesar $60 \%$ mendapatkan nilai rerata keseluruhan yang paling tinggi dibandingkan dengan ketiga formulasi lainnya dengan besar persentase keseluruhan adalah 3,40.

Rasa makanan dapat dinilai berdasarkan aroma, dan rasa. Rasa merupakan penentu tingkat kesukaan dan daya terima konsumen terhadap suatu produk. Rasa whole banana (musa paradisiaca l.) biskuit akan terasa pahit seiring penambahan dan peningkatan konsentrasi tepung kulit pisang kepok yang digunakan. Hasil uji organoleptik dari segi 
rasa tidak berbeda nyata pada tingkat sebelum kulit pisang jadikan tepung terlebih kesukaan pada kategori biasa saja yang artinya tidak ada perubahan rasa walaupun telah ditambahkan tepung kulit pisang kepok dengan nilai 3,37 (Tabel 1). Hasil ini cukup bagus karena rasa merupakan faktor penting dalam menentukan kualitas suatu bahan pangan. Selain itu tepung kulit pisang masih memberikan rasa yang khas, sehingga sebagian besar panelis masih merasakannya kekhasan rasa pisang.

Pengujian fisik (tekstur) dilakukan pada whole banana (musa paradisiaca l.) biskuit memberikan hasil yang tidak berbeda nyata dalam hal kekerasan, kelembutan, konsistensi dan kerenyahan dengan tingkat kesukaan biasa menuju suka. Tingkat kesukaan panelis dari tampilan fisik whole banana (musa paradisiaca l.) biskuit berada pada skala 3,47 dari skala 5 (Tabel 1) dan mengindikasikan bahwa tidak ada perbedaan yang signifikan. Hal tersebut menunjukkan bahwa formulasi whole banana (musa paradisiaca l.) biskuit tidak mempengaruhi tingkat konsumsi biskuit karena tingkat penerimaannya sama.

Kandungan serat pada kulit pisang tidak signifikan mempengaruhi kerenyahan whole banana (musa paradisiaca l.) biskuit. Hal ini disebabkan adanya perlakuan yaitu dahulu kulit pisang dihaluskan. Biskuit yang dihasilkan cenderung tidak berongga (padat) tetapi renyah.

Karakter warna whole banana (musa paradisiaca l.) biskuit pada semua hasil penelitian menunjukkan bahwa warna coklat dan semakin ditambahkan konsentrasi tepung pisangnya akan semakin coklat menuju kehitaman. Hasil atribut penilaian warna dalam penelitian ini menunjukan warna coklat tua dengan tingkat kesukaan panelis sebesar 3,23 yang dikategorikan normal (Tabel 1). Warna coklat yang dihasilkan dari tepung kulit pisang merupakan efek dari reaksi browning yaitu reaksi oksidasi dengan udara sehingga terbentuk reaksi pencokelatan oleh pengaruh enzim yang terdapat dalam kulit pisang (browning enzymatic). Pembentukan warna coklat pada biskuit dikarenakan adanya enzim yang merupakan reaksi antara oksigen dan suatu senyawa fenol yang dikatalisis oleh polifenol oksidase. Enzim tersebut dapat mengkatalis oksidasi senyawa fenol menjadi quinon dan kemudian dipolimerasi menjadi pigmen melaniadin yang berwarna coklat ${ }^{10}$.

Atribut penilaian terhadap aroma whole banana (musa paradisiaca l.) biskuit adalah normal dengan nilai kesukaan sebesar 
3,53 (Tabel 1). Definisi normal dalam hal ini adalah aroma normal khas pisang ${ }^{7}$ Artinya, aroma normal yang diperoleh pada pembuatan whole banana (musa paradisiaca l.) biskuit tidak seperti aroma normal tepung terigu atau tepung sejenis lainnya karena tepung kulit pisang kepok memiliki karakteristik aroma tepung tersendiri.

\section{Penentuan Formula Terpilih}

Hasil whole banana (musa paradisiaca l.) biskuit F3 (60\%) sebagai formula terpilih ini sesuai dengan beberapa penelitian terkait substitusi tepung kulit pisang kepok yang telah dilakukan oleh penelitian-penelitian sebelumnya. Formulasi biskuit pisang raja dengan subsitusi tepung bayam dengan kisaran substitusi tepung tepung kulit pisang antara lain, 65\% sampai $75 \%$ dan dihasilkan formula terpilih adalah substitusi $71 \%$. Konsentrasi yang digunakan lebih tinggi dibandingkan pada penelitian ini yang disebabkan karena adanya campuran tepung bayam sedangkan pada penelitian ini hanya menggunakan tepung kulit pisang kepok $^{13}$. Penelitian mengenai cookies substitusi tepung kulit pisang kepok menunjukkan hasil formula terpilih yaitu dengan konsentrasi penambahan tepung kulit pisang sebesar $90 \%$ didapatkan cookies dengan tekstur warna yang coklat kehitaman dan rasa yang agak pahit, hal ini disebabkan karena penggunaan tepung pisang kepok yang terlalu banyak namun masih dapat diterima oleh panelis secara keseluruhan ${ }^{8}$.

\section{Analisis Proksimat}

Pada penelitian ini dilakukan analisis proksimat pada tepung kulit pisang kepok dan whole banana (musa paradisiaca l.) biskuit. Berdasarkan Tabel 3 dan Tabel 4 menunjukan bahwa kandungan karbohidrat, protein, kadar air dan kadar abu tidak mengalami perubahan yang signifikan. Namun, berbeda halnya dengan kandungan lemak, jumlah energi dan serat pangannya yang menunjukan perbedaan nilai yang signifikan karena terdapat selisih yang besar. Perbedaan kandungan lemak disebabkan karena tambahan kandungan lemak pada bahan-bahan lain seperti telur, margarin dan susu. Lemak merupakan jenis cadangan energi yang artinya pasti akan mempengaruhi jumlah energi yang terkandung pada whole banana (musa paradisiaca l.) biskuit.

\section{Karbohidrat}

Karbohidrat banyak terkandung dalam bahan makanan berupa pati, gula dan serat kasar. Berdasarkan Standar Nasional Indonesia (01-2973-1992) kandungan karbohidrat pada biskuit minimal $70 \%$. Berdasarkan jumlah karbohidratnya, biskuit dengan tambahan kulit pisang masih dibawah 
SNI yaitu sebesar 63,18\% (Tabel 4), hal ini disebabkan kandungan lemak biskuit dengan penambahan tepung kulit pisang cukup tinggi. Semakin tinggi kandungan lemak biskuit mengandung kandungan karbohidrat yang semakin rendah. Kandungan karbohidrat rendah yang diduga akibat pengurangan tepung terigu diganti dengan tepung kulit pisang yang rendah protein dan karbohidrat. Kadar karbohidrat pada tepung kulit pisang kepok sebesar 82,59\%, sehingga jika dibandingkan dengan hasil yang diperoleh Djunaedi, kadar karbohidrat penelitian ini lebih rendah ${ }^{9}$.

\section{Lemak}

Selain protein, lemak merupakan salah satu komponen penting dalam pembuatan biskuit karena berfungsi sebagai penambah aroma dan menghasilkan produk yang teksturnya renyah. Lemak dalam pengolahan biskuit berperan sebagai pelembut adonan, pemberi rasa gurih, dan dapat meningkatkan volume bahan. Karakteristik adonan ditentukan oleh penggunaan jenis lemak yang berbeda ${ }^{10}$. Kadar lemak yang semakin tinggi pada whole banana (musa paradisiaca l.) biskuit formula terpilih disebabkan oleh penambahan tepung kulit pisang kepok yang semakin banyak.
Menurut Standar Nasional Indonesia (01-2973-1992) kandungan lemak pada biskuit adalah minimal 9,5\%. Kandungan lemak biskuit dengan penambahan tepung kulit pisang $60 \%$ lebih tinggi dari standar yang dipersyaratkan yaitu sebesar 21,58\% (Tabel 4). Hasil kadar lemak tertinggi sebesar 23,66\% dan kadar lemak terendah sebesar $18,14 \%$. Kadar lemak penelitian ini berada ditengah-tengah dari kadar lemak yang diperoleh Lestari ${ }^{11}$. Tingginya kadar lemak pada biskuit dapat disebabkan oleh bahan yang digunakan seperti mentega, margarin, susu bubuk cukup tinggi lemak ${ }^{12}$.

\section{Protein}

Berdasarkan Tabel 4 diketahui bahwa kadar protein pada pada whole banana (musa paradisiaca l.) biskuit di tingkatan $60 \%$ sebesar 5,64\% (Tabel 4). Hal ini disebabkan karena tepung kulit pisang kepok mengandung protein rendah. Penambahan protein dari telur, margarin dan susu skim tidak meningkatkan kadar protein secara signifikan. Hasil penelitian menunjukkan bahwa dengan penambahan tepung kulit pisang pisang akan mengurangi kadar protein namun masih memenuhi standar dan layak untuk dikonsumsi. 


\section{Kadar Serat}

Kandungan serat whole banana (musa paradisiaca l.) biskuit lebih tinggi dibandingkan dengan Standar Nasional Indonesia yang menyatakan bahwa kandungan serat maksimal adalah maksimal $0,5 \%$. Pada formulasi terpilih diperoleh nilai kandungan serat sebesar 16,64\% (Tabel 4). Tingginya kandungan serat pada whole banana (musa paradisiaca l.) biskuit kemungkinan besar disebabkan karena subsitusi penambahan tepung pisang kepok lebih banyak dibandingkan dengan tepung terigu. Kandungan serat yang tinggi pada biskuit akan mempengaruhi tekstur biskuit dan membuat konsistensi agak keras, kasar dan rapuh. semakin tinggi kandungan serat pada whole banana (musa paradisiaca l.) biskuit maka semakin baik untuk pencernaan, sehingga biskuit tersebut juga dapat dijadikan alternatif makanan untuk diet.

\section{Kadar Air dan Abu}

Hasil pengujian kadar air pada whole banana (musa paradisiaca l.) biskuit (Tabel 4) menunjukan nilai $6.64 \%$ yang berada diatas kadar air standar SNI yang mensyaratkan kandungan air didalam biskuit adalah dibawah $5 \%^{13}$. Tingginya kadar air yang diperoleh disebabkan kulit pisang yang dijadikan tepung merupakan kulit pisang kepok yang sudah matang, untuk mengetahui kadar air pada pisang kepok berdasarkan tingkat kematangan pisang dan diperoleh hasil bahwa kadar air pisang kepok berwarna hijau sebesar 2,42\% sedangkan untuk pisang yang warna kuning sebesar $9,64 \%$. Penelitian ini juga sejalan dengan hasil yang didapatkan oleh Murtada et all yang menyimpulkan bahwa rasio peningkatan kadar air pada kulit dan buah pisang kepok akan semakin meningkat berdasarkan fungsi kematangan ${ }^{14}$.

Kandungan mineral pada whole banana (musa paradisiaca l.) biskuit dapat diketahui berdasarkan uji kadar abunya. Pada Tabel 4 diketahui bahwa kadar abu yang diperoleh sebesar 3,11\%. Pengujian kadar air pada tepung pisang kepok dengan diperoleh hasil yang tidak berbeda signifikan dengan hasil pada penelitian ini yaitu berkisar antara 2,00-2,36\% dengan penambahan konsentrasi tepung pisang kepok ${ }^{15}$. Tingginya kadar abu yang diperoleh disebabkan karena pemilihan kulit pisang yang dijadikan tepung merupakan kulit pisang yang berwarna kuning, dimana kadar abu akan semakin meningkat apabila pisang kepok semakin matang $^{16}$.

\section{KESIMPULAN}

Berdasarkan hasil dan pembahasan yang telah dilakukan, dapat ditarik 
kesimpulan bahwa formulasi whole banana (musa paradisiaca l.) biskuit bersubstitusi tepung kulit pisang kepok terpilih adalah formulasi dengan perbandingan substitusi tepung terigu dan tepung pisang kepok sebesar 60\%: 40\% dengan tingkat kepuasan dari panelis pada kategori mennyukai dan memiliki karakteristik kimia antara lain, karbohidrat sebesar $63,18 \%$, lemak sebesar $21,58 \%$, protein sebesar $5,64 \%$, energi sebesar 469,50 kkal/100g, kadar air sebesar $6,49 \%$ dan kadar abu sebesar 3,11\%. Kadar serat yang tinggi pada whole banana (musa paradisiaca l.) biskuit berpotensi mencegah penyakit degeneratif pada lansia.

\section{UCAPAN TERIMA KASIH}

Terimakasih kepada semua pihak yang telah membantu penelitian ini.

\section{DAFTAR RUJUKAN}

1. Kemenkes RI (2017). Profil Kesehatan Indonesia 2016. http://www.depkes.go.id/resources/downl oad/pusdatin/lain-lain/Data dan Informasi Kesehatan Profil Kesehatan Indonesia 2016 - smaller size - web.pdf - Diakses Februari 2020.

2. Yang, J., Wang, H.P., Zhou, L., Xu, C.F. (2012). Effect of dietary fi ber on constipation: A meta Analysis. World
Journal of Gastroenterology, 18(48), 713738.

3. Marjan, A.Q., Marliyati, S.A. (2013). Hubungan antara Pola Konsumsi Pangan dan Aktivitas Fisik dengan Kejadian Osteoporosis pada Lansia di Panti Werdha Bogor. Jurnal Gizi dan Pangan, 8(2), $123-$ 128.

Diakses

dari http://journal.ipb.ac.id/index.php/jgizipan gan/article/ viewFile/7689/5955.

4. Berry Satria H., Yusuf Ahda (2008). Pengolahan Limbah Kulit Pisang Menjadi Pektin Dengan Metode Ekstraksi. Skripsi Universitas Diponegoro. Semarang

5. Kiptiah M., HairiyahN., Nurmalasari A. Pengaruh Substitusi Tepung Kulit Pisang Kepok (Musa paradisiaca 1. L) terhadap Kadar Serat dan Daya Terima Cookies. Jurnal Teknologi Agro-Industri Vol. 5 No. 2 Tahun 2018:66-76.

6. Agustono, Herviana W., Nurhajati T. Kandungan Protein Kasar Dan Serat Kasar Kulit Pisang Kepok (Musa paradisiaca 1.) Yang Difermentasi Dengan Trichoderma Viride Sebagai Bahan Pakan Alternatif Pada Formulasi Pakan Ikan Mas (Cyprinus Carpio). Jurnal Kelautan Vol. 4, No. 1 Tahun 2011:53-59.

7. Mardiah E. 1996. Penentuan aktivitas dan inhibisi enzim polifenol oksidase dari apel 
(Pyrus malus Linn.). Jurnal Kimia Pisang Kepok (Musa paradisiaca 1. Linn). Andalas 2: 2. Jurnal Kimia Khatulistiwa Vol. 8 No. 1

8. Aryani, T. dkk. (2018). Efektivitas Tahun 2019:71-77.

Pengolahan Limbah Kulit Pisang Menjadi

12. Djunaedi, E. (2006). Pemanfaatan Limbah

Donat Ditunjau dari Analisis Fitokimia, Proksimat dan Organoleptik. Laporan Penelitian Hibah Penelitian Dosen Pemula DIKTI 2018 Universitas 'Aisyiyah Yogyakarta: Yogyakarta

Kulit Pisang Sebagai Sumber Pangan Alternatif dalam Pembuatan Cookies. Program Studi Kimia Fakultas Matematika dan Ilmu Pengetahuan Alam Universitas Pakuan

9. Waysima, Adawiyah, Dede, R. 2010. Evaluasi Sensori. Bogor: Fakultas Teknologi Pertanian Insitut Pertanian Bogor.

10. Damayanti R., Ansharullah, Asyik N. Formulasi Biskuit Pisang Raja (Musa paradisiaca 1. L.) dengan Substitusi Tepung Bayam (Amaranthus Hybridus L.) Dan Kontribusinya Terhadap Angka Kecukupan Gizi (AKG) Bagi Remaja Putri. Jurnal Sains dan Teknologi Pangan Vol. 4 No. 4 Tahun 2019:2410-2424.

11. Devi I.C., Ardiningsih P., Idiawati N. 13. [BSN] Badan Standardisasi Nasional. 2011. SNI 2973:2011 Biskuit. Jakarta. Hal: 2-3.

14. Sari, D.N., (2015). Ini 105 Produk yang Wajib SNI, Diambil dari alamat website:http://industri.bisnis.com/read/201 5111 9/257/493753/ini-105-produkyangwajib-sni, Diakses pada 1 Mei 2018.

15. Desiliani, Harun N., Fitriani S. Pemanfaatan Tepung Pisang Kepok dan Buah Nangka Kering dalam Pembuatan Snack Bar. Jurnal Teknologi Pangan Vol. Kandungan Gizi Dan Organoleptik Cookies Tersubstitusi Tepung Kulit 13 No. 1 Tahun 2019: 1-11. 